\title{
Sprawozdanie z XVI Międzynarodowego Seminarium z cyklu „Metodologia badań systemów społecznych”
}

DOI: 10.19195/2083-7763.9.23

W dniu 20 grudnia 2018 odbyło się XVI Międzynarodowe Seminarium z cyklu „Metodologia badań systemów społecznych”. Wykład pt. Metodyka szkoleń ratownictwa chemicznego w Państwowej Straży Pożarnej wygłosił mł. bryg. dr inż. Artur Ankowski z Centralnej Szkoły Państwowej Straży Pożarnej w Częstochowie.

W trakcie wykładu podjęte zostały ogólne kwestie dotyczące systemu ratowniczo-gaśniczego, w tym ratownictwa chemicznego i ekologicznego. Uwaga została zwrócona na zagadnienie organizacji szkoleń i doskonalenia zawodowego funkcjonariuszy PSP w zakresie ratownictwa chemicznego i ekologicznego. W tym celu PSP dysponuje kilkoma ośrodkami, w których funkcjonariusze zdobywają zawód lub podnoszą kwalifikacje zawodowe. W ramach funkcjonowania zawodowego w PSP funkcjonariusze zdobywają zawód strażaka w Szkole Podoficerskiej PSP w Bydgoszczy. Zawód technika pożarnictwa funkcjonariusze mogą uzyskać w szkołach aspirantów PSP w Krakowie, Częstochowie oraz Poznaniu, natomiast inżynierów pożarnictwa na studiach pierwszego stopnia i magistrów inżynierów pożarnictwa na studiach drugiego stopnia kształci Szkoła Główna Służby Pożarniczej w Warszawie. Ponadto komendy wojewódzkie PSP dysponują ośrodkami szkolenia, w których na bieżąco prowadzone jest doskonalenie zawodowe funkcjonariuszy.

Zaprezentowane zagadnienia związane z metodyką zajęć, organizacją ćwiczeń i szkoleń podczas działań ratowniczych w ramach programów nauczania w zawodzie strażak, technik pożarnictwa oraz inżynier pożarnictwa obejmowały informacje dotyczące szkoleń: z ratownictwa chemicznego i ekologicznego realizowanych przez krajowy system ratowniczo-gaśniczy $\mathrm{w}$ zakresie podstawowym, specjalistycznych $\mathrm{w}$ zakresie ratownictwa chemicznego i ekologicznego oraz specjalistycznych w zakresie przeciwdziałania zagrożeniom chemicznym, biologicznym, radiologicznym, nuklearnym i wybuchowym. Szkolenia obejmują: montaż i demontaż zastawów do dekontaminacji, czyli usuwania szkodliwych zanieczyszczeń powstałych w wyniku pożarów lub innych zdarzeń losowych, obsługę sprzętu będącego na wyposażeniu lekkiego samochodu rozpoznania chemicznego, a także specjalistyczne szkolenie w zakresie transportu towarów niebezpiecznych.

Zadania PSP i zakresy tematyczne szkoleń uzależnione są od poziomu specjalizacji grup chemicznych. Szkolenia z ratownictwa chemicznego i ekologicznego realizowane przez krajowy system ratowniczo-gaśniczy w zakresie podstawowym obejmują takie tematy, jak: znajomość i umiejętność wykorzystywania środków ochrony indywidualnej, znajomość technik i umiejętność obsługi urządzeń pomiarowych, znajomość technik służących do kontrolowania emisji substancji niebezpiecznych, umiejętność podejmowania działań ratowniczych, znajomość zasad dekontaminacji. Szkolenia specjalistyczne w zakresie ratownictwa chemicznego i ekologicznego obejmują: znajomość środków ochrony indywidualnej ratownika, umiejętność dokonywania pomiarów i pobierania próbek, znajomość technik kontrolowania emisji substancji niebezpiecznych, znajomość technik przemieszczania materiałów niebezpiecznych, zasady dekontaminacji, zasady ograniczania rozlewów olejowych, znajomość elementów taktyk stosowanych w działaniach ratownictwa chemicznego i ekologicznego. Natomiast szkolenia specjalistyczne w zakresie przeciwdziałania zagrożeniom chemicznym, biologicznym, radiologicznym, nuklearnym 
i wybuchowym dotyczą: umiejętności poboru i analizy próbek, znajomości materiałów oraz urządzeń wybuchowych, umiejętności prowadzenia działań ratowniczych podczas zdarzeń o charakterze chemicznym, biologicznym, radiologicznym, nuklearnym i wybuchowym (CBRNE). Wszystkie szkolenia realizowane są - w zależności od potrzeb w formie pokazów lub ćwiczeń oraz ćwiczeń laboratoryjnych.

Skuteczność podejmowanych działań w zakresie ratownictwa chemicznego i ekologicznego w obszarze systemu ratowniczo-gaśniczego zależy od poziomu wyszkolenia strażaków ratowników, ich wyposażenia, a także stosowania nowych technologii.

W seminarium udział wzięło 25 uczestników, w tym 7 osób z władz dziekańskich i dyrektorskich Instytutu Socjologii, zaproszeni goście, doktoranci i studenci z Akademickiego Koła Naukowego „Security\&Society” IS UWr oraz studenci z Koła Naukowego PWSZ w Nysie.

Monika Zawartka

ORCID: 0000-0002-2896-3197

Sprawozdanie z konferencji „Konsument w zmieniającym się otoczeniu społecznym. Między pragmatyzmem a dyferencjacją"

DOI: 10.19195/2083-7763.9.24

W dniu 23 października 2017 roku odbyła się we Wrocławiu interdyscyplinarna konferencja naukowa zorganizowana przez Zakład Zachowań Konsumenckich Instytutu Socjologii Uniwersytetu Wrocławskiego. Współorganizatorem wydarzenia były Stowarzyszenie Dziennikarzy i Wydawców „Repropol” oraz Polskie Towarzystwo Komunikacji Społecznej. Uroczystego otwarcia konferencji dokonali: rektor Uniwersytetu Wrocławskiego - prof. dr hab. Adam Jezierski oraz prodziekan Wydziału Nauk Społecznych dr hab. Marcelina Zuber. Uczestników konferencji przywitała także przewodnicząca Rady Programowej - prof. dr hab. Wanda Patrzałek.

Celem konferencji była dyskusja wokół konsumpcji, wskazująca na jej centralny status jako kategorii opisującej kondycję naszych czasów. W literaturze treść rozważań na temat konsumpcji pełna jest sprzeczności i antynomii, takich jak: „autonomia-dominacja”, „racjonalność-nieracjonalność, „wolność-zniewolenie”, „nadmiar-umiarkowanie”, „instrumentalność-ekspresyjność”, „indywidualność-uspołecznienie”, „masowość-zróżnicowanie" itp. Próba uporządkowania wiedzy o konsumencie zderza się z problemem nieustannie zmieniającego się otoczenia (gospodarczego, instytucjonalnego, kulturowego, politycznego itp.), wobec którego konsumenci podejmują adaptacyjne i dialektyczne zmiany. Dotychczasowe paradygmaty i prawdy naukowe (np. racjonalność działań i stabilność rynków) są kwestionowane, co skłania do poszukiwania nowych perspektyw i podejmowania nowych badań zachowań konsumenta.

Problematyka konferencji obejmowała następujące bloki tematyczne: gospodarstwo domowe wobec zmian w otoczeniu, stare i nowe trendy konsumpcji, alternatywne formy 